\title{
Minimizing Soil Nitrogen Leaching by Changing Furrow Irrigation into Sprinkler Fertigation in Potato Fields in the Northwestern China Plain
}

\author{
Wenzhu Yang ${ }^{1,2} \mathbb{D}^{\text {, Yan Jiao }}{ }^{1,2, *}$, Mingde Yang ${ }^{1,2}$, Huiyang Wen ${ }^{1,2}$, Peng Gu ${ }^{1,2}$, Jie Yang ${ }^{1,2}$, \\ Lijia Liu ${ }^{1,2}$ and Junxia Yu 1,2 \\ 1 Inner Mongolia Key Laboratory of Environmental Chemistry, Inner Mongolia Normal University, \\ Hohhot 010022, China; yangwzh@imnu.edu.cn (W.Y.); m15949470966_1@163.com (M.Y.); \\ zonglgnj@yeah.net (H.W.); meiblnmgdx@126.com (P.G.); jiayqnd@yeah.net (J.Y.); \\ yanghaotong88@163.com (L.L.); maxiuzhi66@yeah.net (J.Y.) \\ 2 College of Chemistry and Environmental Sciences, Inner Mongolia Normal University, Hohhot 010022, China \\ * Correspondence: jiaoyan@imnu.edu.cn
}

Received: 19 July 2020; Accepted: 4 August 2020; Published: 7 August 2020

\begin{abstract}
Irrigation water is limiting for crop production in arid areas and application rates of fertilizers often exceed crop requirements, resulting in high accumulation of nitrate nitrogen $\left(\mathrm{NO}_{3}{ }^{-}-\mathrm{N}\right)$ in the soil. Management practices play a significant role in the leaching of $\mathrm{NO}_{3}{ }^{-}-\mathrm{N}$. This experiment compares the effects of traditional furrow irrigation and sprinkler fertigation on the soil $\mathrm{NO}_{3}{ }^{-}-\mathrm{N}^{-}$ concentration trend throughout the cropping season in potato fields in China. Two irrigation systems that were fertilized, namely by furrow (NF-FI) and sprinkler fertigation (NF-SI), and two controlling without any fertilizer (C-FI and C-SI) were tested in the same experimental site for three consecutive years. Both the NF-FI soils and NF-SI soils with three replications and fertilizer applications of $273 \mathrm{~kg} \mathrm{~N} \mathrm{ha}{ }^{-1}$ exhibited a different trend of $\mathrm{NO}_{3}{ }^{-}-\mathrm{N}$ accumulation at different depths of soil profile. However, the magnitude of $\mathrm{NO}_{3}{ }^{-}-\mathrm{N}$ accumulation was low in the NF-SI soil profile. In NF-SI treatments, higher $\mathrm{NO}_{3}{ }^{-}-\mathrm{N}$ was observed at 20-40 cm soil layer. In the NF-FI, the concentration of the highest nitrate was observed at the $40-120 \mathrm{~cm}$ soil layer. The concentrations of $\mathrm{NO}_{3}{ }^{-}-\mathrm{N}$ in the fertilized soil were higher than those of the control soil for each irrigation system. Residual levels of $\mathrm{NO}_{3}{ }^{-} \mathrm{-N}$ in the soil depth of 40-120 cm from NF-FI were 1.54, 3.45 and 5.28 times higher than NF-SI after harvesting potatoes from 2015 to 2017. In NF-FI treatments, apparent nitrogen loss was 234.7, 237.5 and $276.7 \mathrm{~kg} \mathrm{ha}^{-1}$ after harvesting potatoes in 2015, 2016 and 2017. Meanwhile, apparent nitrogen loss from NF-SI treatments was only $161.9,132.1$ and $148.9 \mathrm{~kg} \mathrm{ha}^{-1}$, which was $31.0 \%, 44.4 \%$ and $46.2 \%$ lower than that of NF-FI in 2015, 2016 and 2017, respectively. The risk of $\mathrm{NO}_{3}{ }^{-}-\mathrm{N}$ leaching below the root zone from NF-FI was higher than that from NF-SI. It has been demonstrated that sprinkler fertigation can also be used as a tool for mitigating $\mathrm{NO}_{3}{ }^{-}-\mathrm{N}$ accumulation and apparent nitrogen loss.
\end{abstract}

Keywords: sprinkler fertigation; potato; nitrate nitrogen; furrow irrigation; apparent nitrogen loss

\section{Introduction}

Nitrogen $(\mathrm{N})$ is both an essential nutrient and a major pollutant in agricultural ecosystems [1]. Nitrogen input worldwide mainly comes from the application of chemical nitrogen fertilizer. The low efficiency of nitrogen fertilizer is mainly attributed to the loss of soil nitrogen caused by unreasonable use of water and fertilizer [2,3]. The peculiarity of nitrate nitrogen $\left(\mathrm{NO}_{3}{ }^{-}-\mathrm{N}\right)$, such as its leaching susceptibility compared to the other nitrogen form (ammonium nitrogen) in the soil, has been reported [1-5]. $\mathrm{NO}_{3}{ }^{-}-\mathrm{N}$ in the soil is rapidly solubilized and moves with water, causing $\mathrm{N}$ losses due 
to the low adsorption capacity of soil to $\mathrm{NO}_{3}{ }^{-}-\mathrm{N}[4,5]$. The results of some field experiments have suggested that $\mathrm{NO}_{3}{ }^{-}-\mathrm{N}$ leaching responds non-linearly to increasing $\mathrm{N}$ inputs. $\mathrm{NO}_{3}{ }^{-}-\mathrm{N}$ leaching is mainly affected by irrigation measures, nitrogen fertilizer management, crop system, soil management and soil type [6,7]. Irrigated agriculture has been identified as a significant source of $\mathrm{NO}_{3}{ }^{-}-\mathrm{N}$ pollution [8]. Changes in irrigation systems mainly affect the mineralization and leaching of nitrogen by changing the soil water movement and affecting the distribution of available nitrogen in soil [9].

Furrow irrigation is currently the most common system used in many agricultural production areas around the world [8]. However, drought events have forced farmers to restrict agricultural irrigation in this region [10], and some farmers are considering changing from furrow irrigation to a water saving irrigation system, such as sprinkler irrigation, which is generally considered a way to use water more efficiently [11].

Sprinkler fertigation is the integration of water and fertilizer, which is one of the most widely used water saving and fertilizer saving irrigation methods [12]. The wetting front in the soil profile is shallow under sprinkler fertigation, compared with furrow irrigation. The leaching of $\mathrm{NO}_{3}{ }^{-}-\mathrm{N}$ caused by different water distributions and its impact on the environment are different from sprinkler fertigation and furrow irrigation. At present, research on soil nitrogen distribution under sprinkler fertigation mainly focuses on the state of the art of the fixed sprinkler fertigation in wheat and corn fields [12-15]. However, the study of $\mathrm{NO}_{3}{ }^{-}-\mathrm{N}$ distribution, nitrogen balance and apparent nitrogen loss under sprinkler fertigation with low energy precision application (LEPA) sprinklers and furrow irrigation in potato fields is a lack of data support in arid and semi-arid areas. It is of great significance for the sustainable development of agriculture and the environment to optimize the irrigation and nitrogen management scheme of potato fields and provide technical guidance for the exploration of a standardized production mode suitable for high potato yield.

Based on the previously mentioned literature review, it is expected that the furrow irrigation and sprinkler fertigation methods will influence $\mathrm{NO}_{3}{ }^{-}-\mathrm{N}$ movement due to the different wetted forms in the soils. This experiment was performed to (I) determine the soil $\mathrm{NO}_{3}{ }^{-}-\mathrm{N}$ distribution patterns under sprinkler fertigation and furrow irrigation as a function of depth, lateral distance and fertilizer application method; (II) determine changes in soil $\mathrm{NO}_{3}{ }^{-}-\mathrm{N}$ before and after the potato growth period; (III) determine the cumulative residual $\mathrm{NO}_{3}{ }^{-}-\mathrm{N}$ in the soils after harvesting potatoes, and (IV) determine the nitrogen balance under furrow and sprinkler fertigation.

\section{Experiments}

\subsection{Description of Study Site}

The field experiments were conducted at Hohhot Potato Experimental Station (HPES), Chinese Academy of Sciences, between 19 May 2015 and 23 September 2017. HPES is located in the suburbs of Hohhot, Inner Mongolia ( $40^{\circ} 45^{\prime} 34^{\prime \prime} \mathrm{N}, 111^{\circ} 41^{\prime} 56^{\prime \prime} \mathrm{E}, 1045 \mathrm{~m}$ above sea level). The annual precipitation is around $335 \mathrm{~mm}$, concentrated between July and August. The spring and early summer are normally dry. The soil is sandy loam with an average bulk density of $1.29 \mathrm{~g} \cdot \mathrm{cm}^{-3}$. Other physico-chemical properties of the upper $(0-30 \mathrm{~cm})$ soil horizon: $\mathrm{pH}, 7.79$; organic matter, $3.43 \mathrm{~g} \mathrm{~kg}^{-1}$; total nitrogen, $0.25 \mathrm{~g} \mathrm{~kg}^{-1}$; Olsen $\mathrm{P}, 4.68 \mathrm{mg} \mathrm{kg}^{-1}$; available potassium, $184.03 \mathrm{mg} \cdot \mathrm{kg}^{-1}$. Field soil water capacity (gravity content) is about $44.5 \%$. The soluble mineral content of the area's groundwater is less than $0.5 \mathrm{~g} \mathrm{l}^{-1}$.

\subsection{Experimental Design}

Two treatments for sprinkler fertigation and traditional furrow irrigation were designed as different irrigation regimes. The two treatments for sprinkler fertigation were fertilizing (NF-SI) and a control without any fertilizer (C-SI). The two treatments for furrow irrigation were fertilizing (NF-FI) and a control without any fertilizer (C-FI). 
All treatments were replicated three times, with the experimental plots arranged in a complete randomized block design. Each plot had one valve, one flow meter and one pressure gauge to measure the irrigation water volume and control the operating pressure by the valve. The low energy precision application (LEPA) sprinkler tape with $2.8 \mathrm{~m}$ sprinkler spacing and a flow rate of $10.2 \mathrm{~mm}$ per hour at the operating pressure of $0.1 \mathrm{MPa}$ were mounted on $130 \mathrm{~cm}$ high-risers above the center of raised beds. Sprinkler fertigation with a walking speed of $30 \mathrm{~m} \cdot \mathrm{h}^{-1}$ was automatically controlled by a computer. Furrow irrigation was provided by water pipes along the furrows. Length of the furrow was $11.2 \mathrm{~m}$. The spacing of the raised bed was $0.3 \mathrm{~m}$ high and $0.9 \mathrm{~m}$ wide, with the top of bed being $0.3 \mathrm{~m}$ wide for planting potatoes (Figure 1).

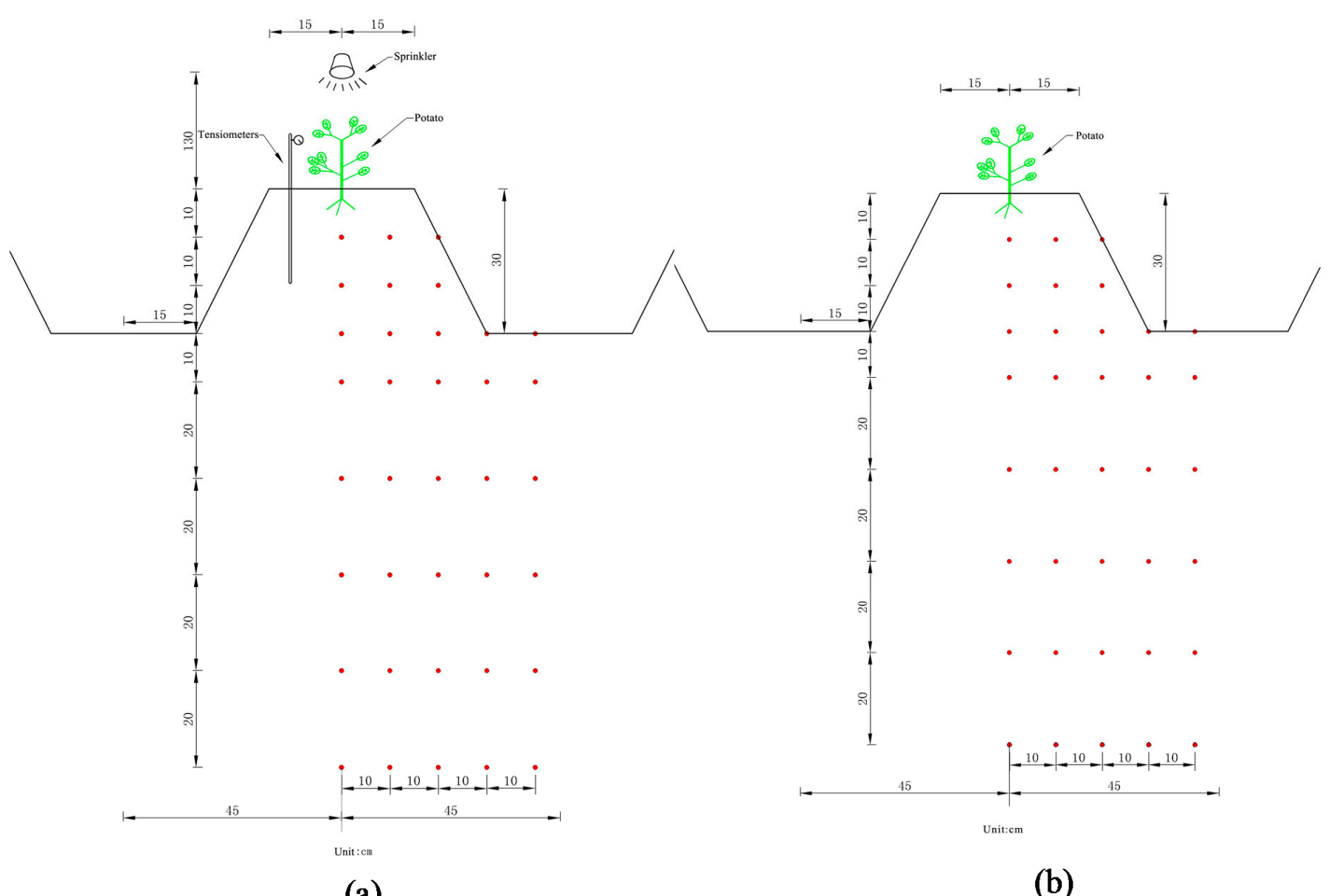

(a)

(b)

Figure 1. (a) A schematic diagram of sampling points in the soil from sprinkler fertigation. (b) A schematic diagram of sampling points in the soil from furrow irrigation.

\subsection{Field Management}

Each plot was $11.2 \times 7.2 \mathrm{~m}$ and contained eight raised beds. Potato (Solanum tuberosum L. cv. Favorita) seed pieces with sowing rate of $2250 \mathrm{~kg} \mathrm{ha}^{-1}$ were planted in the center of the raised beds at $0.2 \mathrm{~m}$ intervals and $0.1 \mathrm{~m}$ depth. Each plot consisted of 448 plants.

Fertilizer was applied uniformly to each fertilizing treatment when the soil was plowed. The furrows were constructed using a seeding machine. In sprinkler fertigation and furrow irrigation, fertilizers were first broadcast on the ridges by hand and then irrigated. Fertilizer applications were $140 \mathrm{~kg} \mathrm{~N} \mathrm{ha}^{-1}$ for N, P and K compound fertilizer. The date and amount of the top dressing fertilization in two different ways in the treatments was performed based on the local fertilizing habits. Urea and potassium nitrate at a rate of $133 \mathrm{~kg} \mathrm{~N} \mathrm{ha}^{-1}$ were distributed for top dressing after potato emergence. In sprinkler fertigation, fertilizers were dissolved in the irrigation water and applied to the soil together with the water. In furrow irrigation, fertilizers were applied on the ridges by hand. The subplots were independent but irrigated at the same time. 
The first irrigation began on 19 May 2015, 25 May 2016 and 15 May 2017, immediately after the potatoes were planted. Water application intensity in the first was $40 \mathrm{~mm}(6 \mathrm{~min})^{-1}$ for sprinkler fertigation. After the potatoes' emergence, the sprinkler field was irrigated when the mean soil matric potential (SMP) of the $0-20 \mathrm{~cm}$ soil layer decreased to around $-20.0 \mathrm{kPa}$. The irrigation duration was determined by the wetting of main potato-root zones and was usually around $1.5 \mathrm{~min}$, with around $10 \mathrm{~mm}$ of water each time by automatic control with computer. Sprinkler fertigation was stopped $20 \mathrm{~d}$ before harvesting.

The date and water amount of furrow irrigation was implemented based on the local irrigation practices. Irrigation was uniformly applied three times throughout the crop growing season: once when potatoes were planted, the second application during the tuber set stage and the third application during the tuber bulking stage. Irrigation frequency was higher while total irrigation water was smaller in the sprinkler-irrigated field than in the furrow-irrigated field in the three experimental seasons. The total amounts of water applied for sprinkler and furrow irrigation during the study period were 191.4 and $609.6 \mathrm{~mm}$ in 2015, 200.7 and $601.8 \mathrm{~mm}$ in 2016, 205.0 and $593.7 \mathrm{~mm}$ in 2017, respectively.

The potatoes required around 105 days to reach maturity and were harvested in September for total yield.

\subsection{Sampling and Analysis on Soil and Crop}

During the cropping season, soil samples from each subplot were collected during seedling stage, tuber formation stage, tuber swelling stage and maturity stage, from the center of the ridge to the side of the ridge, $0-40 \mathrm{~cm}$ in the horizontal direction, collecting one point at each $10 \mathrm{~cm}$ intervals. The five sampling points in the horizontal direction were vertically downward from the ground, 0-40 cm, one point at each $10 \mathrm{~cm}$ interval and $40-120 \mathrm{~cm}$, one point at each $20 \mathrm{~cm}$ interval (Figure 1). Forty points were collected for each treatment. The collected soil samples, packed into sealed bags, were quickly brought back to the laboratory, where they were analyzed immediately using continuous-flow analysis [16]. The ten potato plants were selected randomly to measure their nitrogen uptake in each plot, every two weeks.

$\mathrm{NO}_{3}{ }^{-}-\mathrm{N}$ and $\mathrm{NH}_{4}{ }^{+}-\mathrm{N}$ in the soils were determined by extracting $8 \mathrm{~g}$ of fresh soil with $60 \mathrm{ml}$ of deionized water and $50 \mathrm{ml}$ of $\mathrm{KCl}(0.01 \mathrm{M})$, respectively [17]. They were measured by continuous-flow analysis (Futura, Alliance, France). The amount of nitrogen absorbed in the plants was determined by digesting and measured by KjelMaster K-375 (K-375, BUCHI, Switzerland). Precipitation data were collected from a portable weather station located in the potato experimental farm. Soil moisture content was measured by the TDR350-indicating instrument (SPECTRUM Inc., ST Petersburg, FL, USA) [18]. Irrigation time was controlled by a tensiometer under sprinkler fertigation [17].

\subsection{Calculation Method of Nitrogen in Soil}

Regarding the calculation of soil nitrogen, $\mathrm{NO}_{3}{ }^{-}-\mathrm{N}$ is the main form of nitrogen in upland soils in Northern China. When calculating the soil nitrogen balance, the content of $\mathrm{NH}_{4}{ }^{+}-\mathrm{N}$ in the soil was not considered, mainly because of the $\mathrm{NH}_{4}{ }^{+}-\mathrm{N}^{\prime}$ s impact on leaching non-susceptibility, and the $\mathrm{NH}_{4}{ }^{+}-\mathrm{N}$ content in the arid regions is very low, and its variation range is small in the Northwestern China Plain $[19,20]$.

Apparent nitrogen loss is an important indicator for evaluating nitrogen use status, which is always associated with substantial reactive $\mathrm{N}$ loss through hydrological and gaseous pathways $[21,22]$ and was calculated as [23,24]: 


$$
\mathrm{ANL}=\mathrm{IN}+\mathrm{ANM}+\mathrm{NF}+\mathrm{NR}+\mathrm{NI}-\mathrm{NA}-\mathrm{NRS}_{(0-40 \mathrm{~cm})}
$$

where $\mathrm{ANL}$ is apparent nitrogen loss, including nitrogen leaching and gas nitrogen loss, such as $\mathrm{N}_{2}$, $\mathrm{NO}_{\mathrm{x}}, \mathrm{N}_{2} \mathrm{O}, \mathrm{NH}_{3}$, where the unit is $\mathrm{kg} \mathrm{N} \mathrm{ha}^{-1}$; IN is initial nitrogen of soil in the depth from 0 to $120 \mathrm{~cm}$, where the unit is $\mathrm{kg} \mathrm{N} \mathrm{ha}^{-1}$; ANM is apparent nitrogen mineralization $\left(\mathrm{kg} \mathrm{N} \mathrm{ha}^{-1}\right)$, which is estimated as the difference between nitrogen output (nitrogen absorbed by crops plus nitrogen residual in the soil after harvest) and nitrogen input (initial nitrogen of soil before planting) in soil of a depth from 0 to $120 \mathrm{~cm}$ in the control without any fertilizer [25]; NF is nitrogen fertilizer, where the unit is $\mathrm{kg} \mathrm{N} \mathrm{ha}^{-1}$; $\mathrm{NR}$ is from rainfall, where the unit is $\mathrm{kg} \mathrm{Nha}^{-1}$; $\mathrm{NI}$ is from irrigation water, where the unit is $\mathrm{kg} \mathrm{N} \mathrm{ha}^{-1}$; NA is nitrogen absorbed by crops after harvest, where the unit is $\mathrm{kg} \mathrm{N} \mathrm{ha}^{-1}$;

NRS $\left(\mathrm{kg} \mathrm{N} \mathrm{ha}^{-1}\right)$ is the nitrogen residual of soil after harvest at a depth ranging from 0 to $120 \mathrm{~cm}$, which is calculated using the following equation:

$$
\begin{gathered}
\mathrm{NRS}_{(0-40 \mathrm{~cm})}=\sum_{\mathrm{i}=1}^{\mathrm{n}} \mathrm{C}_{\mathrm{i}} \times \mathrm{BD} \times \mathrm{SD} \times 0.1 \\
\mathrm{NRS}_{(40-120 \mathrm{~cm})}=\sum_{\mathrm{i}=1}^{\mathrm{n}} \mathrm{C}_{\mathrm{i}} \times \mathrm{BD} \times \mathrm{SD} \times 0.1
\end{gathered}
$$

where $\mathrm{C}_{\mathrm{i}}$ is the $\mathrm{NO}_{3}{ }^{-}-\mathrm{N}$ concentration of soil after harvest at a depth of 0 to $120 \mathrm{~cm}$ and the unit is $\mathrm{mg} \mathrm{kg}^{-1}$; BD is soil bulk density, where the unit is $\mathrm{g} \mathrm{cm}^{-3}$; $\mathrm{SD}$ is soil depth, where the unit is $\mathrm{cm}$. Soil samples were collected at $10 \mathrm{~cm}$ intervals from 0 to $40 \mathrm{~cm}$ and $20 \mathrm{~cm}$ intervals from $40 \mathrm{~cm}$ to $120 \mathrm{~cm}$.

\subsection{Data Statistics and Drafting}

Data calculations were carried out using Excel 2017 software. Origin Pro8 and Sigmaplot 13 (Systat Software, Inc., Santa Clara, CA, USA) were used for drafting. One-way analysis of variance (ANOVA) was used to analysis the significances of difference by SPSS 22.0 (SPSS Inc., Chicago, IL, USA), in Tukey's test, in which multiple comparisons of means were implemented using the least significant difference at the 0.05 probability level.

\section{Results}

\subsection{Changes in Precipitation and Temperature}

The atmospheric temperature showed a basically consistent trend of change from April to October in 2015, 2016 and 2017. The temperature began to increase gradually in April and was higher from July to August than other months (Figure 2). The temperature (mean value of the three years) was $21.8^{\circ} \mathrm{C}, 22.7^{\circ} \mathrm{C}$ and $21.1^{\circ} \mathrm{C}$ in 2015,2016 and 2017 , respectively. The frequency of rainfall during the potato growing season in 2016 was higher than that in 2015 and 2017. There was no difference in the total rainfall of the crop growing season in 2015, 2016 and 2017, which were $219.5 \mathrm{~mm}, 196.7 \mathrm{~mm}$ and $201.8 \mathrm{~mm}$, respectively (Figure 2). 

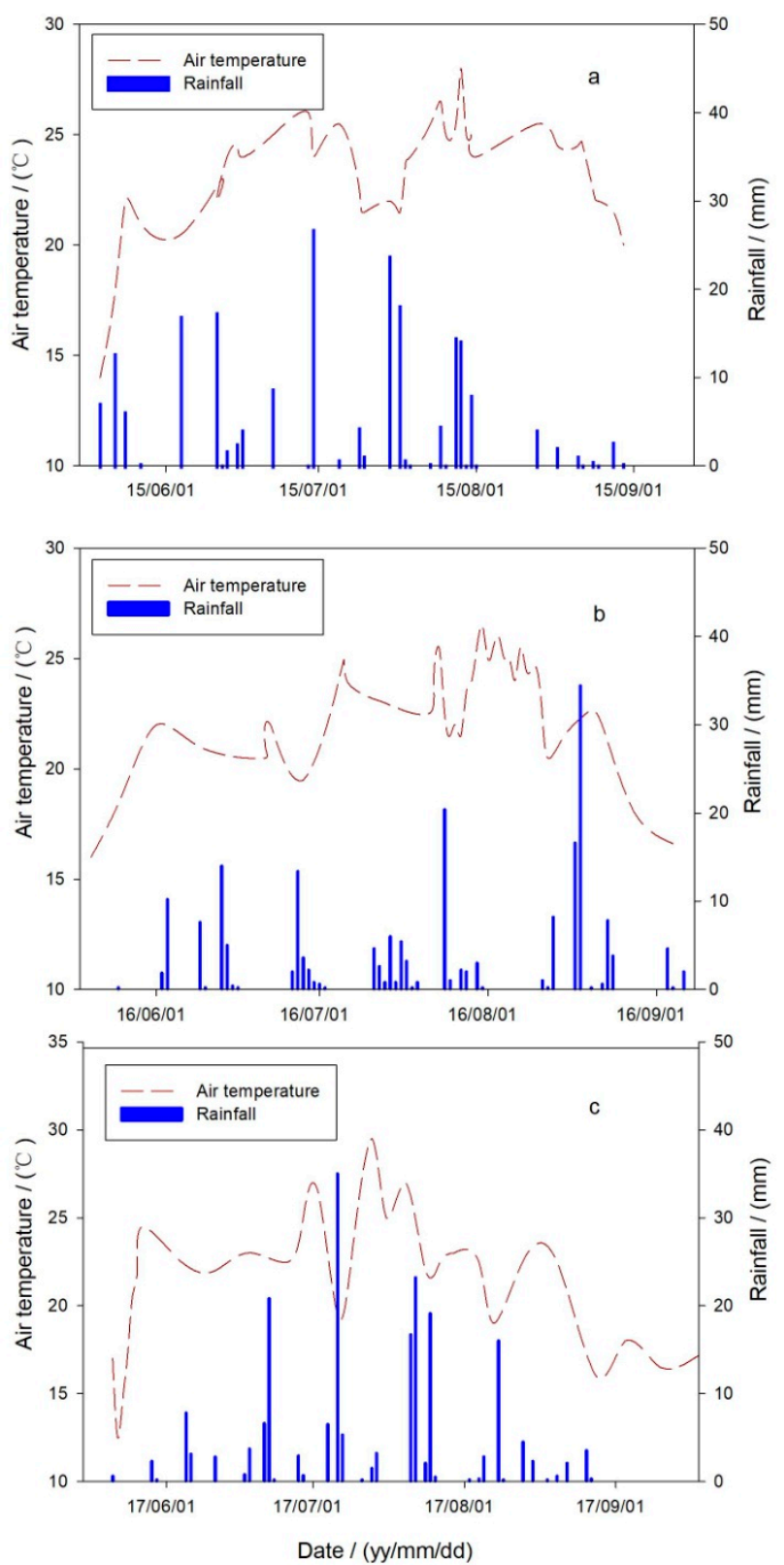

Figure 2. Temperature and rainfall measured at the potato experimental farm in 2015 (a), 2016 (b) and 2017 (c). The rainfall values are the sum of daily rainfall. Air temperature is a daily average throughout the crop growing season.

\subsection{Distribution Characteristics of Soil $\mathrm{NO}_{3}{ }^{-}-\mathrm{N}$ Under Furrow Irrigation and Sprinkler Fertigation}

The concentration of $\mathrm{NO}_{3}{ }^{-}-\mathrm{N}$ in soil of $0-40 \mathrm{~cm}$ gradually increased with the increase in soil depth from potato fields under two irrigation methods. However, significant seasonal variations in $\mathrm{NO}_{3}{ }^{-}-\mathrm{N}$ concentration from the depth of $40-80 \mathrm{~cm}$ in soil were exhibited from furrow irrigation and sprinkler fertigation during tuber set stages and tuber bulking stages in 2015, 2016 and 2017 (Figure 3). The $\mathrm{NO}_{3}{ }^{-}-\mathrm{N}$ increased significantly in the soil of $40-80 \mathrm{~cm}$ with increasing depth under furrow irrigation. The highest content of $\mathrm{NO}_{3}{ }^{-}-\mathrm{N}$ was concentrated in the soil layer of $40-80 \mathrm{~cm}$ in depth and $40 \mathrm{~cm}$ in the horizontal distance from the ridge center outside the potato root region under furrow irrigation for both tuber set stages and tuber bulking stages, which were $36.14,88.59$ and $96.24 \mathrm{mg} \mathrm{kg}^{-1}$ from 2015 to 2017. However, significant differences in the concentration of $\mathrm{NO}_{3}{ }^{-}-\mathrm{N}$ were observed at depths of soil between 0 and $40 \mathrm{~cm}$ and between 40 and $80 \mathrm{~cm}$ under sprinkler fertigation 
$(p<0.01) . \mathrm{NO}_{3}{ }^{-}-\mathrm{N}$ content from the depth of $40-80 \mathrm{~cm}$ in soil was lower than $0-40 \mathrm{~cm}$ under sprinkler fertigation. There was the highest content of $\mathrm{NO}_{3}{ }^{-}-\mathrm{N}$ in the soil layer of 30-40 cm in depth and $20 \mathrm{~cm}$ in the horizontal distance from ridge center near the potato root region, which were 23.34, 31.76 and $48.46 \mathrm{mg} \mathrm{kg}^{-1}$ under sprinkler fertigation. The seasonal average content of soil $\mathrm{NO}_{3}{ }^{-}-\mathrm{N}$ was 17.85 , 24.74 and $28.01 \mathrm{mg} \mathrm{kg}^{-1}$ at the depth of $0-120 \mathrm{~cm}$ from furrow irrigation, which was higher than that $\left(7.74,9.31\right.$ and $\left.10.45 \mathrm{mg} \mathrm{kg}^{-1}\right)$ from sprinkler fertigation from 2015 to 2017 . The $\mathrm{NO}_{3}{ }^{-}-\mathrm{N}$ concentrations of the fertilized soil were higher than those of the control soil for each irrigation system.
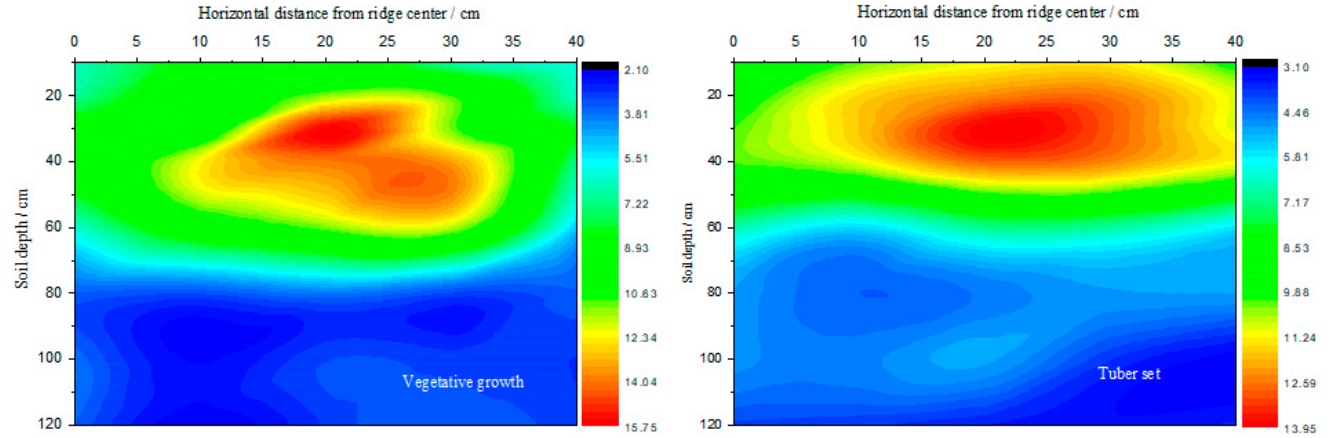

Horizontal distance from ridge center $/ \mathrm{cm}$
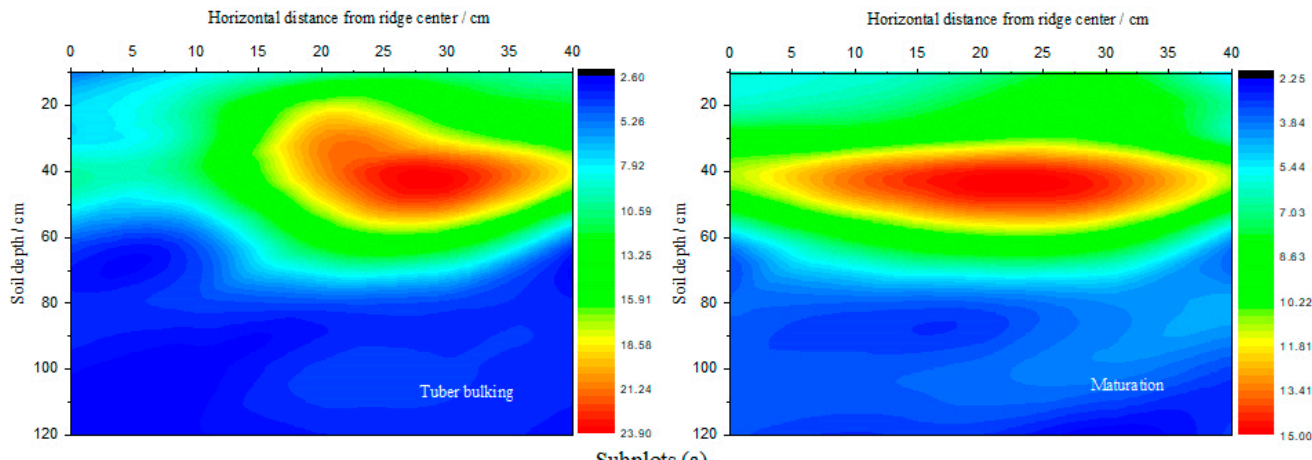

Subplots (a)
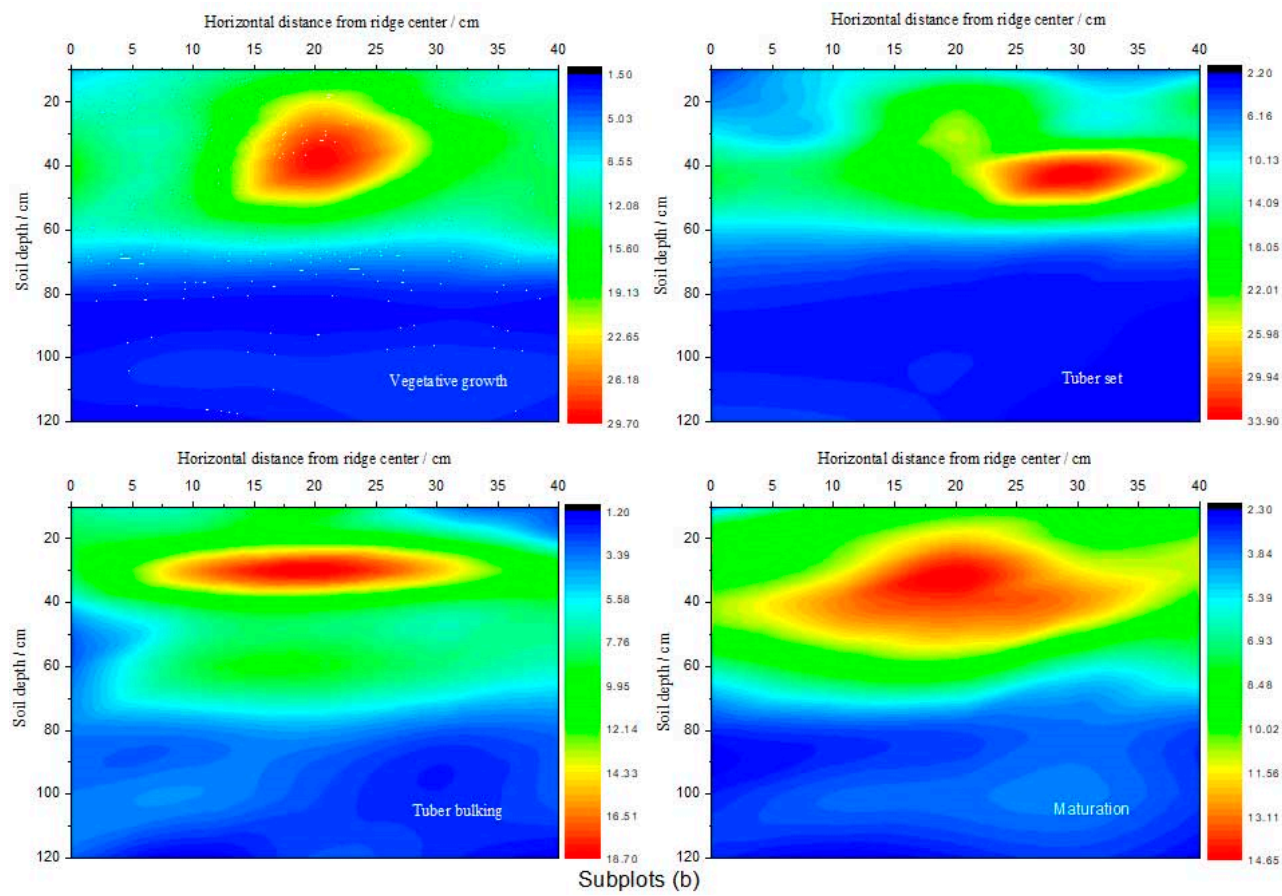

Figure 3. Cont. 

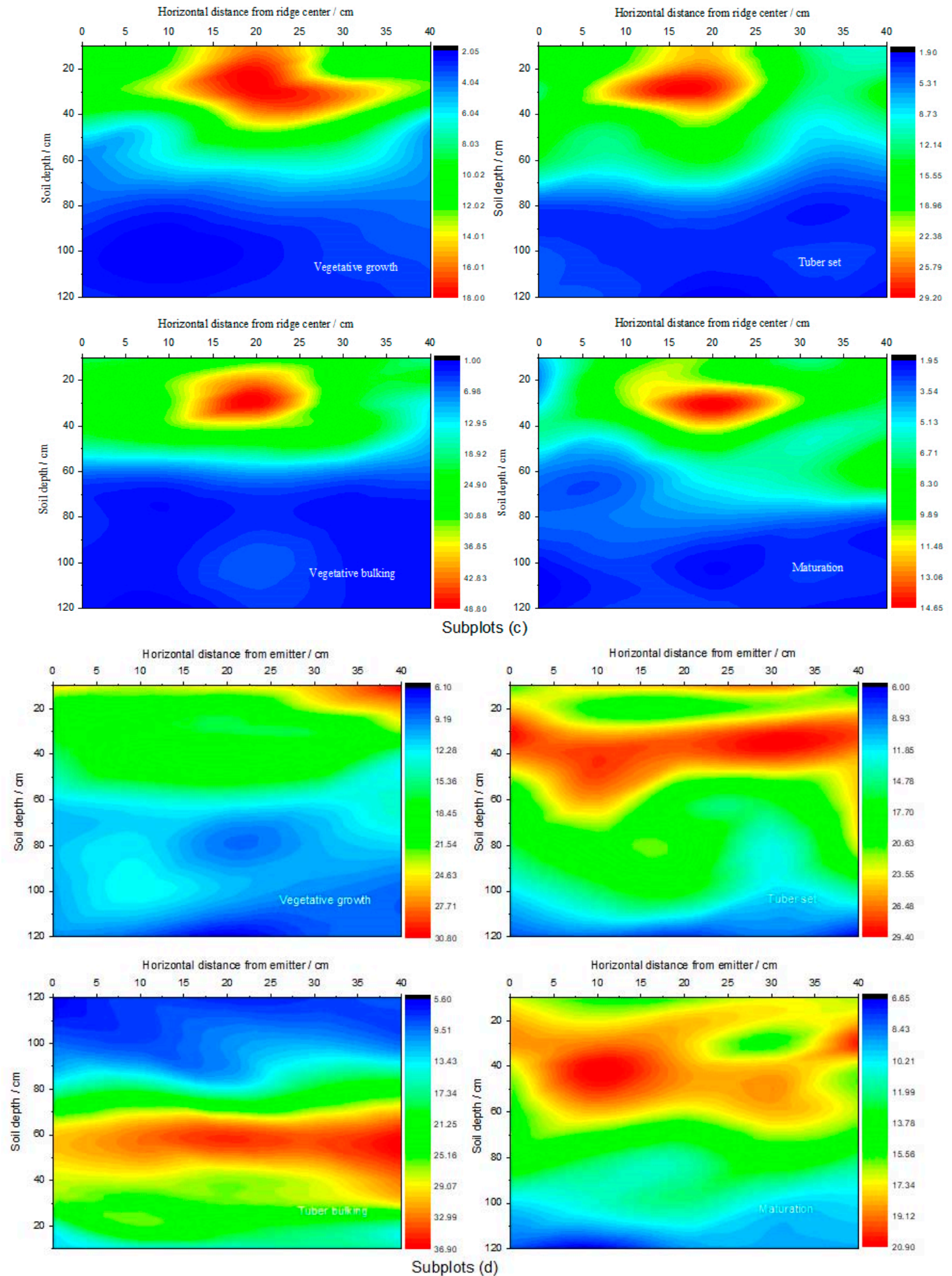

Figure 3. Cont. 

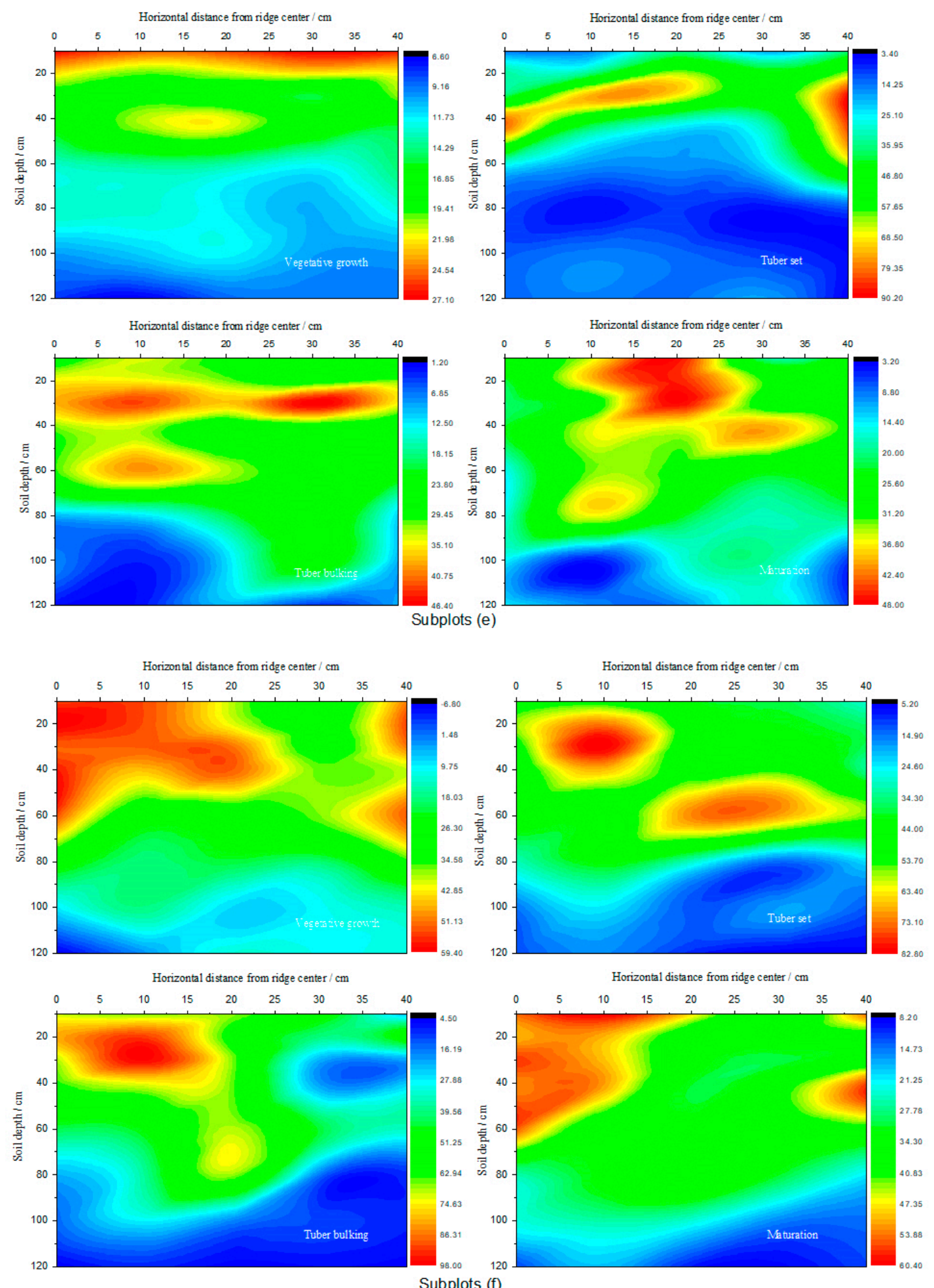

Figure 3. Distribution of $\mathrm{NO}_{3}{ }^{-}-\mathrm{N}$ in the fertilized soil with depths and horizontal distances in subplots. $(\mathbf{a}-\mathbf{c})$ : Nitrogen fertilizer (NF) under sprinkler fertigation (SI) in 2015, 2016 and 2017. (d-f): NF from furrow irrigation in 2015, 2016 and 2017.

\subsection{Changes in Soil $\mathrm{NO}_{3}{ }^{-}-\mathrm{N}$ Before and After Potato Growth Period}

The $\mathrm{NO}_{3}{ }^{-}-\mathrm{N}$ concentration of soil after harvesting potatoes was compared with that before planting. The variation of $\mathrm{NO}_{3}{ }^{-}-\mathrm{N}$ in the soil depth of $40-120 \mathrm{~cm}$ was negative under sprinkler fertigation. There was no $\mathrm{NO}_{3}{ }^{-}-\mathrm{N}$ leaching out of the potato root region, which ranged from 0 to 
$40 \mathrm{~cm}$ in soil depth after each potato growing season under sprinkler fertigation from 2015 to 2017 . The maximum reduction of $\mathrm{NO}_{3}{ }^{-}-\mathrm{N}$ concentration under sprinkler fertigation was $2.21 \mathrm{mg} \mathrm{kg}^{-1}$ in 2017 (Figure 4). However, the variation of nitrogen in soil of $40-120 \mathrm{~cm}$ was positive under furrow irrigation. The increase in soil $\mathrm{NO}_{3}{ }^{-}-\mathrm{N}$ content after the growing season resulted in the leakage of $\mathrm{NO}_{3}{ }^{-}-\mathrm{N}$ from the potato root region. The depth of soil with the highest increase of $\mathrm{NO}_{3}{ }^{-}-\mathrm{N}$ was $40-80 \mathrm{~cm}$, with increases of 5.09, 14.19 and $13.03 \mathrm{mg} \mathrm{kg}^{-1}$ from 2015 to 2017, respectively.

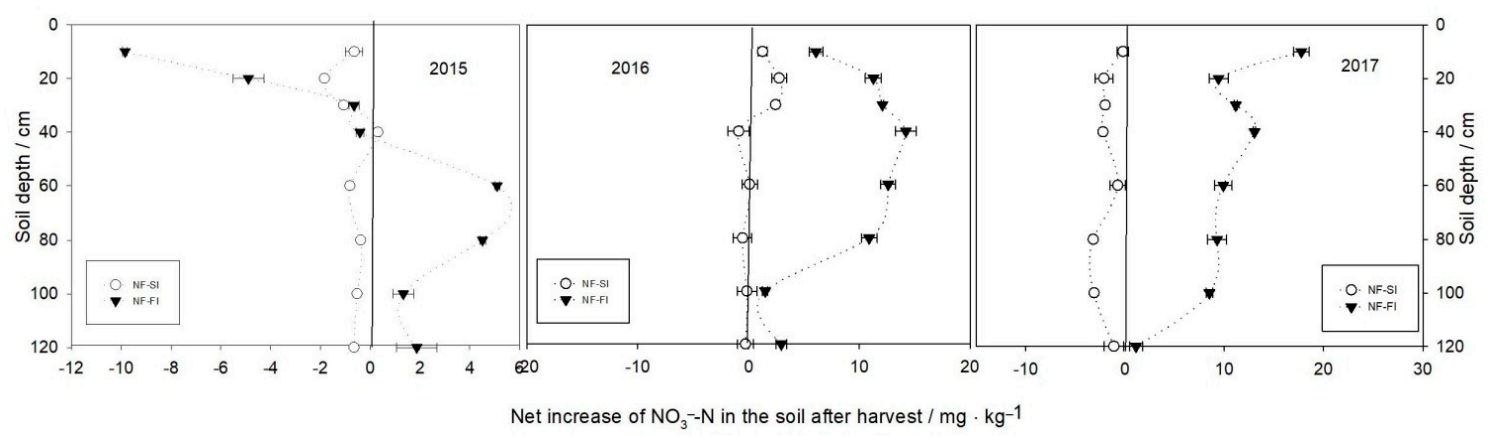

Figure 4. Net increase of $\mathrm{NO}_{3}{ }^{-}-\mathrm{N}$ from different soil depths after harvest in 2015, 2016 and 2017.

Vertical bars indicate the mean and standard error.

\subsection{Cumulative Residual of $\mathrm{NO}_{3}{ }^{-}-\mathrm{N}$ in the Soil of 40-120 cm after Harvesting Potatoes}

The cumulative residual of $\mathrm{NO}_{3}{ }^{-}-\mathrm{N}$ was $70.2,88.5$ and $123.7 \mathrm{~kg} \mathrm{~N}^{-1}$ at a depth of $40-120 \mathrm{~cm}$ under furrow irrigation, which was significantly higher than that of sprinkler fertigation after harvesting potatoes from 2015 to $2017(p<0.01)$. The cumulative residual of $\mathrm{NO}_{3}{ }^{-}-\mathrm{N}$ in soil of $40-120 \mathrm{~cm}$ was 27.6, 19.9 and $19.7 \mathrm{~kg} \mathrm{ha}^{-1}$ under sprinkler fertigation after harvesting potatoes from 2015 to 2017 (Figure 5). The cumulative residual of $\mathrm{NO}_{3}{ }^{-}-\mathrm{N}$ from traditional furrow irrigation was 1.54, 3.45 and 5.28 times more than that of sprinkler fertigation in 2015, 2016 and 2017. The cumulative residual of $\mathrm{NO}_{3}{ }^{-}-\mathrm{N}$ in the soil of 40-120 cm under traditional furrow irrigation increased year by year, while the cumulative residual of $\mathrm{NO}_{3}{ }^{-}-\mathrm{N}$ in soil of sprinkler fertigation decreased gradually during the three growing seasons in 2015, 2016 and 2017. The cumulative residual of $\mathrm{NO}_{3}{ }^{-}-\mathrm{N}$ in the fertilized soils were higher than those of the unfertilized treatments for each irrigation system. The $\mathrm{NO}_{3}{ }^{-}-\mathrm{N}$ leaching risk was increased in the soils under traditional furrow irrigation after three years of cultivating potatoes.

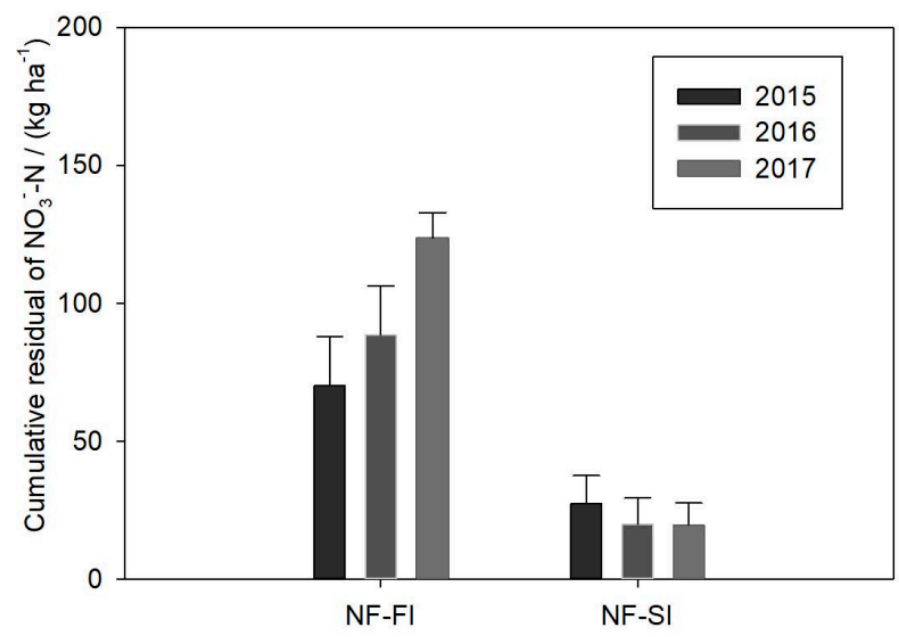

Figure 5. Nitrogen interception with different modes of irrigation after harvest from 2015 to 2017. Vertical bars indicate the mean and standard error. 


\subsection{Nitrogen Balance under Furrow and Sprinkler Fertigation}

The apparent nitrogen loss from furrow irrigation was $234.7,237.5$ and $276.7 \mathrm{~kg} \mathrm{ha}^{-1}$, accounting for $44.0 \%, 41.3 \%$ and $44.8 \%$ of the input of nitrogen in 2015, 2016 and 2017 (Table 1). However, the apparent nitrogen loss under sprinkler fertigation was $161.9,132.1$ and $148.9 \mathrm{~kg} \mathrm{ha}^{-1}$, accounting for $22.9 \%, 25.1 \%$ and $33.7 \%$ of the input of nitrogen from 2015 to 2017 , respectively. The apparent nitrogen loss from sprinkler fertigation was $31.0 \%, 44.4 \%$ and $46.2 \%$ lower than that from furrow irrigation in 2015, 2016 and 2017. The apparent nitrogen loss had been greatly reduced under sprinkler fertigation.

Table 1. Input and output of nitrogen from different irrigation mode from 2015 to 2017.

\begin{tabular}{cccccccccc}
\hline \multirow{2}{*}{ Time } & \multirow{2}{*}{ Treatments } & \multicolumn{4}{c}{ Input/kg·ha $^{-1}$} & \multicolumn{3}{c}{ Output/kg ha $^{\mathbf{1}}$} \\
\cline { 3 - 9 } & & IN & NF & ANM & NR & NI & NRS $_{(\mathbf{0}-\mathbf{4 0} \mathbf{~ c m})}$ & NA & ANL \\
\hline \multirow{2}{*}{2015} & SF & 76.0 & 273.0 & $341.7 \mathrm{a}$ & 12.3 & $2.6 \mathrm{a}$ & $55.0 \mathrm{a}$ & $488.1 \mathrm{a}$ & $161.9 \mathrm{a}$ \\
& FF & 76.0 & 273.0 & $164.1 \mathrm{~b}$ & 12.3 & $8.2 \mathrm{~b}$ & $100.3 \mathrm{~b}$ & $198.0 \mathrm{~b}$ & $234.7 \mathrm{~b}$ \\
2016 & SF & $70.6 \mathrm{a}$ & 273.0 & $167.6 \mathrm{a}$ & 11.6 & $2.6 \mathrm{a}$ & $48.4 \mathrm{a}$ & $345.0 \mathrm{a}$ & $132.1 \mathrm{a}$ \\
& FF & $170.5 \mathrm{~b}$ & 273.0 & $112.1 \mathrm{~b}$ & 11.6 & $8.1 \mathrm{~b}$ & $176.0 \mathrm{~b}$ & $162.0 \mathrm{~b}$ & $237.5 \mathrm{~b}$ \\
2017 & SF & $78.3 \mathrm{a}$ & 273.0 & $75.5 \mathrm{a}$ & 11.7 & $2.7 \mathrm{a}$ & $46.2 \mathrm{a}$ & $246.0 \mathrm{a}$ & $148.9 \mathrm{a}$ \\
& FF & $264.5 \mathrm{~b}$ & 273.0 & $60.2 \mathrm{a}$ & 11.7 & $8.6 \mathrm{~b}$ & $215.2 \mathrm{~b}$ & $126.0 \mathrm{~b}$ & $276.7 \mathrm{~b}$ \\
\hline
\end{tabular}

Note: SF is sprinkler fertigation with fertilizer. FF is furrow irrigation with fertilizer. The inputs are IN, NF, ANM, $\mathrm{NR}$ and NI. The outputs are $\mathrm{NRS}_{(0-40 \mathrm{~cm})}, \mathrm{NA}$ and ANL. IN is initial nitrogen of soil. NF is nitrogen fertilizer. ANM is apparent nitrogen mineralization. NR is nitrogen from rainfall. NI is nitrogen from irrigation. NRS is nitrogen residual of soil. NA is nitrogen absorbed by crops. ANL is apparent nitrogen loss. For each of the two treatments in the same year, means within a column followed by a different letter are significantly different at $p<0.05$.

\section{Discussion}

\subsection{Distribution and Cumulative Residual of $\mathrm{NO}_{3}{ }^{-}-\mathrm{N}$ from Sprinkler Fertigation and Furrow Irrigation}

$\mathrm{NO}_{3}{ }^{-}-\mathrm{N}$ that has accumulated in soils is highly prone to leaching, directly threatening the quality of groundwater. Irrigation water productivity could be significantly affected by the irrigation variables, such as water flow and water volumes, that could regulate nitrate movement inside the soil [13]. Water migrating downward in soil is the main reason for $\mathrm{NO}_{3}{ }^{-}-\mathrm{N}$ leakage [26]. Soil $\mathrm{NO}_{3}{ }^{-}-\mathrm{N}$ leaching loss in arid and semi-arid irrigated areas under furrow irrigation is one of the main ways of nitrogen loss [27]. It is susceptible to leaching $\mathrm{NO}_{3}{ }^{-}-\mathrm{N}$ in soils with high residuals of $\mathrm{NO}_{3}{ }^{-}-\mathrm{N}$ due to excessive irrigation during the cropping season. Therefore, it is essential to optimize agricultural management measures $[28,29]$. In our study, the cumulative $\mathrm{NO}_{3}{ }^{-}-\mathrm{N}$ in the soil layer of $40-120 \mathrm{~cm}$ under sprinkler fertigation was less than that under furrow irrigation throughout the potato growing season. The highest $\mathrm{NO}_{3}{ }^{-}-\mathrm{N}$ content was mainly concentrated in the root zone of the potato. Potatoes can effectively absorb nitrogen from sprinkler fertigation. These results are consistent with the findings of Li et al. (2016) [30] and of Qin (2013) [31]. Leakage of $\mathrm{NO}_{3}{ }^{-}-\mathrm{N}$ under the sprinkler fertigation system was less than that in the furrow irrigation system [30]. Under furrow irrigation, the soil ammonium and nitrate nitrogen content of $102.95 \mathrm{~kg} \mathrm{ha}^{-1}$ was the highest in the soil depth of $60-120 \mathrm{~cm}$ and was 1.36 times higher than that under sprinkler fertigation [31]. Sprinkler fertigation can effectively prevent $\mathrm{NO}_{3}{ }^{-}-\mathrm{N}$ accumulation at depths below $90 \mathrm{~cm}$ on the soil profile, increasing the cumulative peak of nitrate to a depth of $20-40 \mathrm{~cm}$. Sun et al. (2006) showed a peak of soil $\mathrm{NO}_{3}{ }^{-}-\mathrm{N}$ content at a shallower depth in the soil from sprinkler fertigation and mainly distributed in the soil layer of 0-40 $\mathrm{cm}$ compared with furrow irrigation [32].

$\mathrm{NO}_{3}{ }^{-}-\mathrm{N}$ content at different depths of soil was sensitive to irrigation amount. There was a similar trend between changes in $\mathrm{NO}_{3}{ }^{-}-\mathrm{N}$ content and moisture movement with the increase in soil depth. Figure 6 exhibited the distribution of moisture at different depths of soils. The wetted front in the soil profile generally does not exceed $40 \mathrm{~cm}$ under sprinkler fertigation. Little change happened in soil moisture content below $40 \mathrm{~cm}$ of soil profile, and the moisture decreased with the increase in soil depth downward. However, the wetting front of furrow irrigation can reach a depth of $90 \mathrm{~cm}$ in the profile of 
soil. Sprinkler fertigation did not produce deep leakage of water (Figure 6). The depth of 0-40 $\mathrm{cm}$ in the soil is the main region of potato root distribution, where potatoes depend on the roots for water consumption and nutrient uptake. Sprinkler fertigation is conducive to the absorption of water and nitrogen nutrients by crops. Compared with furrow irrigation, water and fertilizer are concentrated in the root zone of crops, are beneficial to crop absorption and utilization and do not easily cause fertilizer residues and groundwater pollution.

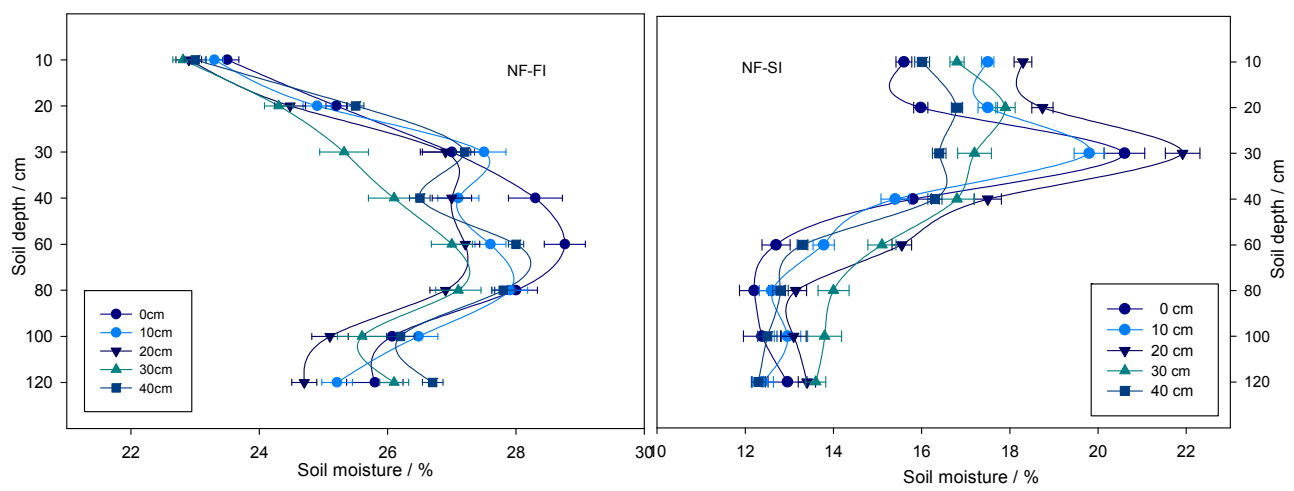

Figure 6. Variation of moisture in the soil with depths and horizontal distances from sprinkler fertigation and furrow irrigation. Vertical bars indicate the mean and standard error.

In our study, the experiment on the potato field was carried out using the integrated technology of water and fertilizer under sprinkler fertigation. The amount of irrigation per time was strictly controlled according to the SMP. The sprinkling field was irrigated when the SMP of the $0-20 \mathrm{~cm}$ soil layer decreased to around $-20.0 \mathrm{kPa}$. The depth of the wetting front in the soil caused by the water from sprinkler fertigation was less than $40 \mathrm{~cm}$ on the soil profile, which was consistent with the depth that $\mathrm{NO}_{3}{ }^{-}-\mathrm{N}$ can reach. The sprinkler fertigation system in this study can ensure that the nitrogen applied to soil is mainly maintained in the root zone of $0-40 \mathrm{~cm}$, which is more conducive to absorption and utilization of nitrogen fertilizer for potato plants (Table 1) and is conducive to improving nitrogen use efficiency and reducing environmental pollution risk. Potato is a typical crop of shallow root. The soil in our study area was sandy soil, which has poor ability to intercept water and fertilizer. From the point of view of environmental friendliness or reduction of environmental risk, the comprehensive technology of sprinkler fertigation nutrient management in potato production has more important practical significance in arid and semi-arid areas.

\subsection{The Nitrogen Balance under Sprinkler Fertigation and Furrow Irrigation}

Excessive furrow irrigation and inappropriate use of $\mathrm{N}$ fertilizer would inevitably increase soil apparent nitrogen loss, resulting in environmental pollution in arid regions [33]. Soil nitrogen balance reflected the relationship between nitrogen input and output in an agricultural system [34]. Soil nitrogen balance had become an important indicator for regional agricultural nitrogen management [35]. Nitrogen balance based on $\mathrm{N}$ inputs and outputs in the soil can measure an agroecosystem's performance and environmental sustainability [36]. In this study, the apparent nitrogen loss under furrow irrigation increased in three growing seasons of potato fields. The apparent nitrogen loss from furrow irrigation reached $234.7,237.5$ and $276.7 \mathrm{~kg} \mathrm{ha}^{-1}$, which accounted for $44.0 \%, 41.3 \%$ and $44.8 \%$ of the input of nitrogen during the three potato growing seasons in 2015, 2016 and 2017. These results were consistent with those of other scholars. Liu et al. (2004) found that the apparent loss of nitrogen was 90-346 kg $\mathrm{ha}^{-1}$ when nitrogen applied to crops was $120-360 \mathrm{~kg} \mathrm{ha}^{-1}$ per season [37]. The apparent nitrogen loss of sprinkler fertigation was $161.9,132.1$ and $148.9 \mathrm{~kg} \mathrm{ha}^{-1}$, accounting for $22.9 \%, 25.1 \%$ and $33.7 \%$ of the input of nitrogen, which was lower than the research results of Li et al. (2015) for summer corn fields under sprinkler fertigation, with a range from $40 \%$ to $71 \%$ [38]. Compared to furrow irrigation, sprinkler fertigation decreased the apparent nitrogen loss by $31.0 \%, 44.9 \%$ and $46.2 \%$ for potatoes, 
respectively, due to lower irrigation and leaching rates. The apparent loss of nitrogen had been greatly reduced from sprinkler fertigation. Among these nitrogen loss pathways, nitrate leaching is considered to be the dominant cause of rising nitrate concentrations in groundwater and directly responsible for ecosystem eutrophication and water quality degradation [39-41]. In these studies, the complexity of measurements of some parameters and constraints on time, labor, and cost resulted in limited analysis of the nitrogen balance in agroecosystems. We were unable to measure dry nitrogen deposition; thus, the system's nitrogen input in our studies may be underestimated.

\section{Conclusions}

The concentration of $\mathrm{NO}_{3}{ }^{-}-\mathrm{N}$ in the soil, changes in soil $\mathrm{NO}_{3}{ }^{-}-\mathrm{N}$ concentration before and after potato growth period, cumulative residual of $\mathrm{NO}_{3}{ }^{-}-\mathrm{N}$ in the soil, nitrogen balance (including input: IN, NF, ANM, NR and NI, output: NRS, NA and ANL) were evaluated in sprinkler and furrow irrigated potato fields for three seasons. Results showed that leaching of $\mathrm{NO}_{3}{ }^{-}-\mathrm{N}$ was significantly correlated with $\mathrm{NO}_{3}{ }^{-}-\mathrm{N}$ accumulation in the soil. The cumulative residual of $\mathrm{NO}_{3}{ }^{-}-\mathrm{N}$ under sprinkler fertigation was less than that under furrow irrigation at the same rate of fertilizer application in potato systems during three growing seasons. Furrow irrigation is considered a major source of $\mathrm{NO}_{3}{ }^{-}-\mathrm{N}$ leaching. Soil $\mathrm{NO}_{3}{ }^{-}-\mathrm{N}$ accumulation and leaching can be reduced by source and process control, such as reducing fertilizer application, and regulating irrigation under sprinkler fertigation. We therefore recommend using sprinkler fertigation as an efficient fertigation method for reducing $\mathrm{NO}_{3}{ }^{-}-\mathrm{N}$ leaching in the Northwestern China Plain.

Author Contributions: Project administration, Y.J.; writing—original draft preparation, W.Y.; formal analysis, M.Y., H.W., P.G., J.Y. (Jie Yang), L.L. and J.Y. (Junxia Yu); data curation, W.Y. All authors have read and agreed to the published version of the manuscript.

Funding: This work was supported by the National Natural Science Foundation of China (Grant No. 41765010), the Program for Young Talents of Science and Technology in Universities of Inner Mongolia Autonomous Region (Grant No. NJYT-20-A04), Project of Grassland Talent of Inner Mongolia Autonomous Region (Grant No. 2020) and the Inner Mongolia Youth Innovative Talent Training Program of Prairie Excellence Project (Grant No. 2016). Many thanks for constructive suggestions to Prof. Kang Yaohu and to the Inner Mongolia Potato Engineering and Technology Research Center for the assistance in maintaining the experiment system.

Acknowledgments: We sincerely appreciate the anonymous reviewers and editors for their critical and valuable comments to help improve this manuscript. The authors are grateful to the Inner Mongolia Key Laboratory of Environmental Chemistry for authorizing the use of the scientific research field and providing help during the research. We acknowledge Yi Wang and Huan Pang for their efforts in installing the multiple sets of observation equipment and for his technical assistance, and we acknowledge the editorial team of the Journal of Agricultural Environmental Science for providing language help and writing assistance.

Conflicts of Interest: The authors declare no conflict of interest.

\section{References}

1. Kadyampakeni, D.M.; Morgan, K.T.; Schumann, A.W.; Nkedi-Kizza, P.; Mahmoud, K. Ammonium and nitrate distribution in soil using drip and microsprinkler irrigation for citrus production. Soil Sci. Soc. Am. J. 2014, 78, 645-654. [CrossRef]

2. Morgan, K.T.; Wheaton, T.A.; Castle, W.S.; Parsons, L.R. Response of young and maturing citrus trees grown on a sandy soil to irrigation scheduling, nitrogen fertilizer rate, and nitrogen application method. Hort. Sci. 2009, 44, 145-150. [CrossRef]

3. Alva, A.K.; Paramasivam, S.; Sajwan, K.; Ali, F.; Jorge, A.D.; Dirceu Mattos, J. Nitrogen and irrigation management practices to improve nitrogen uptake efficiency and minimize leaching losses. J. Crop Imp. 2006, 15, 369-420. [CrossRef]

4. Asadi, M.E.; Clemente, R.S.; Gupta, A.D.; Loof, R.; Hansen, G.K. Impacts of fertigation via sprinkler irrigation on nitrate leaching and corn yield in an acid-sulphate soil in Thailand. Agric. Water Manag. 2002, 52, 197-213. [CrossRef]

5. Di, H.J.; Cameron, K.C. Nitrate leaching in temperate agroecosysterns: Sources, factors and mitigating strategies. Nutr. Cycl. Agroecosyst. 2002, 46, 237-256. [CrossRef] 
6. Mlchabela, M.S.; Madam, A.; Gordon, R.; Burton, D.; Cudmore, D.; Elmi, A.; Hart, W. Gaseous and leaching nitrogen losses from no tillage and conventional tillage systems following surface application of cattle manure. Soil Tillage Res. 2008, 98, 187-199. [CrossRef]

7. Rajput, T.B.S.; Patcl, N. Water and nitrate movement indrip-irrigated onion under fertigation and irrigation treatments. Agric. Water Manag. 2006, 79, 293-311. [CrossRef]

8. Ayars, J.E.; Phene, C.J.; Phene, R.C.; Gao, S.D.; Wang, D.; Day, K.R.; Makus, D.J. Determining pomegranate water and nitrogen requirements with drip irrigation. Agric. Water Manag. 2017, 187, 11-23. [CrossRef]

9. Mosier, A.R.; Bleken, M.A.; Chaiwanakupt, P.; Ellis, E.C.; Freney, J.R.; Howarth, R.B.; Matson, P.A.; Minami, K.; Naylor, R.; Weeks, K.N.; et al. Policy implications of human-accelerated nitrogen cycling. Biogeochemistry 2001, 52, 281-320. [CrossRef]

10. Adopció de Measures Excepcionals i D'emergència en Relació Amb la Utilització Dels Recursos Hidrics, 2nd ed.; Diari Oficial de la Generalitat de Catalunya: Barcelona, Spain, 2007; pp. 84-86.

11. Souza, C.F.; Folegatti, M.V.; Or, D. Distribution and storage characterization of soil solution for drip irrigation. Irrig. Sci. 2009, 27, 277-288. [CrossRef]

12. Sun, Z.Q.; Kang, Y.H.; Jiang, S.F. Effect of sprinkler and border irrigation on topsoil structure in winter wheat field. Pedosphere 2010, 20, 419-426. [CrossRef]

13. Liu, H.J.; Kang, Y.H.; Yao, S.M.; Sun, Z.Q.; Liu, S.P.; Wang, Q.G. Sprinkler or surface irrigation in the north China plain. Irrig. Drain. 2013, 62, 37-49. [CrossRef]

14. Lv, G.H.; Kang, Y.H.; Li, L.; Liu, S.P. Nutrient distribution, growth, and water use efficiency in maize following winter wheat irrigated by sprinklers or surface irrigation. Irrig. Drain. 2011, 60, 338-347. [CrossRef]

15. Pang, X.P.; Leley, J.; Wu, L. Irrigation quantity and uniformity and nitrogen application effects on crop yield and nitrogen leaching. Soil Sci. Soc. Am. J. 1997, 61, 257-261. [CrossRef]

16. Kagata, H.; Ohgushi, T. Non-additive effects of leaf litter and insect frass mixture on decomposition processes. Ecol. Res. 2012, 27, 69-75. [CrossRef]

17. Yang, W.Z.; Kang, Y.H.; Feng, Z.W.; Gu, P.; Wen, H.Y.; Liu, L.J.; Jia, Y.Q. Sprinkler irrigation is effective in reducing nitrous oxide emissions from a potato field in an arid region: A two-year field experiment. Atmosphere 2019, 10, 1. [CrossRef]

18. Yang, W.Z.; Yang, M.D.; Wen, H.Y.; Jiao, Y. Global warming potential of $\mathrm{CH}_{4}$ uptake and $\mathrm{N}_{2} \mathrm{O}$ emissions in saline-alkaline soils. Atmos. Environ. 2018, 191, 172-180. [CrossRef]

19. Shi, Z.L.; Li, D.D.; Jing, Q.; Cai, J.; Jiang, D.; Cao, W.X.; Dai, T.B. Effects of nitrogen applications on soil nitrogen balance and nitrogen utilization of winter wheat in a rice-wheat rotation. Field Crop. Res. 2012, 127, $241-247$. [CrossRef]

20. Liu, X.J.; Ju, X.T.; Zhang, F.S.; Pan, J.R.; Christie, P. Nitrogen dynamics and budgets in a winter wheat-maize cropping system in the North China Plain. Field Crop. Res. 2003, 83, 111-124. [CrossRef]

21. Tilman, D.; Balzer, C.; Hill, J.; Befort, B.L. Global food demand and the sustainable intensification of agriculture. Proc. Natl. Acad. Sci. USA 2011, 108, 20260-20264. [CrossRef]

22. Burney, J.A.; Davis, S.J.; Lobell, D.B. Greenhouse gas mitigation by agricultural intensification. Proc. Natl. Acad. Sci. USA 2010, 107, 12052-12057. [CrossRef]

23. Ma, B.; Dwyer, L.; Gregorich, E. Soil nitrogen amendment effets on seasonal nitrogen mineralization and nitrogen cycling in maize production. Agron. J. 1999, 91, 1003-1009. [CrossRef]

24. Cui, Z.L.; Zhang, F.S.; Chen, X.P.; Dou, Z.X.; Li, J.L. In-season nitrogen management strategy for winter wheat: Maximizing yields, minimizing environmental impact in an over fertilization context. Field Crop. Res. 2010, 116, 140-146. [CrossRef]

25. Cabrera, M.L.; Kissel, D.E. Evaluation of a method to predict nitrogen mineralized from soil matter under field conditions. Soil Sci. Soc. Am. J. 1988, 57, 1071-1076. [CrossRef]

26. Perego, A.; Basile, A.; Bonfante, A.; Mascellis, R.D.; Terribile, F.; Brenn, S.; Acutis, M. Nitrate leaching under maize cropping systemsin Pa Valley (Italy). Agric. Ecosyst. Environ. 2012, 147, 57-65. [CrossRef]

27. Singh, Y.; Rao, S.S.; Regar, P.L. Deficit irrigation and nitrogen effects on seed cotton yield, water productivity and yield response factor in shallow soils of semi-arid environment. Agric. Water Manag. 2010, 97, 965-970. [CrossRef] 
28. Akkal-Corfini, N.; Morvan, T.; Menasseri-Aubry, S.; Bissuel-Bâelaygue, C.; Poulain, D.; Orsini, F.; Leterme, P. Nitrogen mineralization, plant uptake and nitrate leaching following the incorporation of (15N)-labeled cauliflower crop residues (Brassica oleracea) into the soil: A 3-year lysimeter study. Plant Soil 2010, 328, 17-26. [CrossRef]

29. Bouwmeester, R.J.B.; Vlek, P.L.G.; Stumpe, J.M. Effect of environmental factors on ammonia volatilization from a urea-fertilized soil. Soil Sci. Soc. Am. J. 1985, 49, 297-307. [CrossRef]

30. Li, Y.; Liu, H.J.; Huang, G.H.; Zhang, R.H.; Yang, H.Y. Nitrate nitrogen accumulation and leaching pattern at a winter wheat: Summer maize cropping field in the North China Plain. Environ. Earth Sci. 2016, 75, 118. [CrossRef]

31. Qin, Y.L. Water and Fertilizer Use Efficiencies of Potato under Different Fertigation Patterns and Nitrogen Recommendation of Under-Mulch-Drip Irrigated Potato; Inner Mongolia Agricultural University: Huhhot, China, 2013.

32. Sun, Z.Q.; Kang, Y.H.; Liu, H.J. Soil water distribution characteristics and water balance in winter wheat field under sprinkler irrigation. Agric. Res. Arid Area 2006, 24, 100-107.

33. Huang, P.; Zhang, J.; Zhu, A.; Li, X.P.; Ma, D.H.; Xin, X.L.; Zhang, C.Z.; Wu, S.J.; Garland, G.M.; Pereira, E.I.P.; et al. Nitrate accumulation and leaching potential reduced by coupled water and nitrogen management in the Huang-Huai-Hai plain. Sci. Total Environ. 2018, 610, 1020-1028. [CrossRef]

34. Ladha, J.K.; Tirolpadre, A.; Reddy, C.K.; Cassman, K.G.; Verma, S.; Powlson, D.S.; van Kessel, C.; de Richter, B.D.; Richter, D.; Chakraborty, D.; et al. Global nitrogen budgets in cereals: A 50-year assessment for maize, rice, and wheat production systems. Sci. Rep. UK 2016, 6, 19355-19364. [CrossRef]

35. Vitousek, P.M.; Naylor, R.; Crews, T.; David, M.B.; Drinkwater, L.E.; Holland, E.; Johnes, P.J.; Katzenberger, J.; Martinelli, L.A.; Matson, P.A.; et al. Nutrient imbalances in agricultural development. Science 2009, 324, 1519-1520. [CrossRef]

36. Sainju, U.M. Improving nitrogen balance with irrigation practice and cropping system. J. Soil Water Conserv. 2019, 74, 622-631. [CrossRef]

37. Liu, X.J.; Ju, X.T.; Zhang, F.S. Effect of reduced $\mathrm{N}$ application on $\mathrm{N}$ utilization and balance in winter wheat-summer maize cropping system. Chin. J. Appl. Ecol. 2004, 15, 458-462.

38. Li, Y. An Investigation of Different Nitrogen Fertilization Levels on Water and Nitrogen Transport, Transformation, and Their Use Efficiency in Winter Wheat-Summer Maize Field; China Agricultural University: Beijing, China, 2015.

39. Rivett, M.O.; Buss, S.R.; Morgan, P.; Smith, J.W.; Bemment, C.D. Nitrate attenuation in groundwater: A review of biogeochemical controlling processes. Water Res. 2008, 42, 4215-4232. [CrossRef]

40. Robertson, G.P.; Vitousek, P.M. Nitrogen in agriculture: Balancing the cost of an essential resource. Annu. Rev. Environ. Resour. 2009, 34, 97-125. [CrossRef]

41. Sebilo, M.; Mayer, B.; Nicolardot, B.; Pinay, G.; Mariotti, A. Long-term fate of nitrate fertilizer in agricultural soils. Proc. Natl. Acad. Sci. USA 2013, 110, 18185-18189. [CrossRef] 